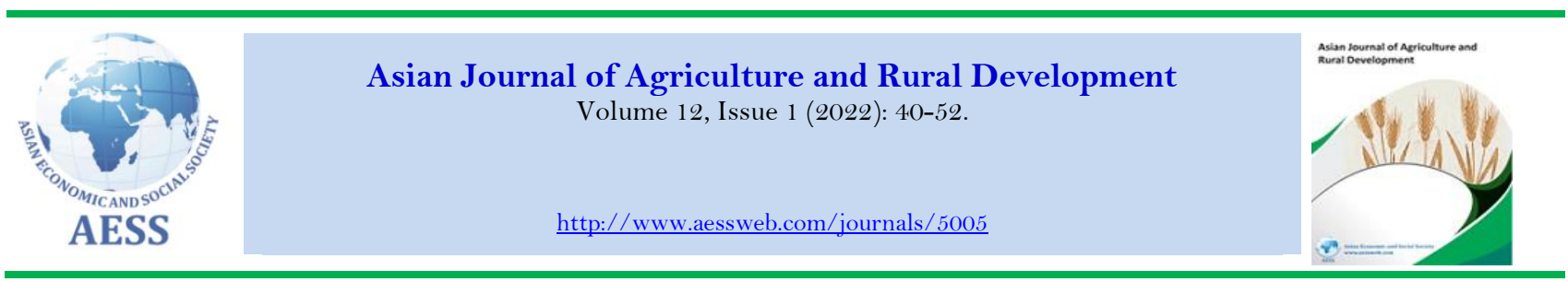

\title{
VERTICAL AND HORIZONTAL COORDINATION IN DEVELOPING COUNTRIES' AGRICULTURE: EVIDENCE FROM VIETNAM AND IMPLICATIONS
}

Tien Dung Khong

\begin{tabular}{l}
\hline Article History \\
\hline Received: 4 October 2021 \\
Revised: 21 January 2022 \\
Accepted: 7 February 2022 \\
Published: 28 February 2022
\end{tabular}

\section{Keywords}

Collective actions

Linkages

Mekong river delta

Rice farming

Small farmers

Value chain.

\author{
School of Economics, Can Tho University, Vietnam.
}

$\triangle \underline{k t d u n g @, c t u . e d u . v n}$

\begin{abstract}
Despite policy reforms and the integration of various linkages in rice production by the Vietnamese government, small-scale farmers' (small farmers') access to the market is limited. A value chain link is a powerful tool for improving small farmers' market access and competitiveness. The benefits of horizontal and vertical coordination on farm household performance were investigated using a dataset of 160 farmers. Twenty-two stakeholders were also directly interviewed to analyze the value chain and farmers' access to markets in the Mekong River Delta, where $75 \%$ of people live in rural areas and contribute to $90 \%$ Vietnam's total rice production. According to our findings, farmers' profits are higher than in the past and total chain economic value is more efficient when farmers participate in vertical or horizontal coordination. Logit regression revealed that the determinants of farmers' decision to participate in cooperatives are training and expected benefits obtained from cooperatives. As a result, collective actions, such as contracting firms and cooperative engagement, are required to assist farmers in accessing the market. The findings also show that participation in value chain links, coordination, and integration benefits food companies significantly. However, financial assistance and insurance are required to adequately cover farmers' production costs and secure contract firms. Furthermore, a written contract should be made to strengthen the value chain. Cooperatives or farmers' organizations can be used as intermediaries to improve vertical and horizontal coordination by establishing links between small farmers and other market stakeholders.
\end{abstract}

Contribution/Originality: This study contributes in the existing literature on value chains in developing countries. It employed a quantitative dataset stratified by vertical and horizontal coordination and reveals the determinants of farmers' decisions to participate in linkages. The findings will be used to enhance the effectiveness and upgrade value chain performance.

DOI: $10.55493 / 5005 . \mathrm{v} 12 \mathrm{i} 1.4429$

$\operatorname{ISSN}(\mathrm{P}):$ 2304-1455/ ISSN(E): 2224-4433

How to cite: Tien Dung Khong (2022). Vertical and Horizontal Coordination in Developing Countries' Agriculture: Evidence from Vietnam and Implications. Asian Journal of Agriculture and Rural Development, 12(1), 40-52. $10.55493 / 5005 . \mathrm{v} 12 \mathrm{i} 1.4429$

(C) 2022 Asian Economic and Social Society. All rights reserved.

\section{INTRODUCTION}

Since 1986, Vietnam, a country with a typical wet rice agricultural civilization, has reformed its agricultural policy and introduced coordination among farmers and those in the value chain. This country's rice sector has promised changes in quantity, switched from importing to exporting, and is now among the top five rice exporters globally (General Statistics Office, 2020). The Mekong River Delta (MRD) is Vietnam's rice-producing belt. With a triumphant story of effective, transformative policies in this sector, MRD farmers contribute to the country's food security and 
exports to Africa and rice-importing countries including the Philippines and Indonesia (General Statistics Office, 2020). Although some rice products have recently begun to approach higher markets, such as Australia, the United States, and European countries, the quality of rice products has not been expected to meet expectations. However, due to pollution, rising input costs, urbanization, and previous policies focused on improving rice production and food security, the agriculture sector is currently dealing with serious issues (World Bank, 2012). Although many innovation programs have been implemented and developed, such as Three Reduced Three Gains (3R3G), Small Farmer Large Field (SFLF), and the provision of more opportunities and higher benefits to those participating in the reform value chain, previous research has revealed market access and chain constraints (General Statistics Office, 2020; Min, 2011).

Vietnam has progressed from a poor agricultural country to one of the top five rice-exporting countries globally. However, MRD rice farmers are receiving only a tiny amount of added value from the value chain, which is insufficient to support their livelihood (General Statistics Office, 2020). As a result, they must seek income diversification through non-farm activities and relocation to other areas. MRD is also one of the most vulnerable areas to climate change, especially during the dry season when fresh water is scarce (Khong, Young, Loch, \& Thennakoon, 2018). In 2019 the country exported 6.37 million tons of rice, worth 2.81 billion dollars (General Statistics Office, 2020). The MRD has long been known as the country's largest food bowl and a vital rice-growing region, covering approximately 4 million hectares (Nguyen, 2015). The MRD produces more than half of Vietnam's rice and accounts for nearly all of the country's rice exports (People's Daily, 2015). In some provinces in the MRD, farmers propagate short-term rice varieties with high yield and good quality for large-scale production. Drought, flooding, saline intrusion, and other climate-related events have directly impacted the region's output, post-harvest preservation, and product consumption. From December 2019 to February 2020, the National Center for Hydro-Meteorological Forecasting predicted that the Mekong River's flow into the MRD would be minimal, potentially shortening flow from the Mekong River upstream to the MRD by $30-45 \%$. As a result, the MRD would see significant saline intrusion that will happen more rapidly and forcefully, especially in coastal areas such as Bac Lieu, Ben Tre, Hau Giang, Kien Giang, Soc Trang, and Tra Vinh (Khong, Loch, \& Young, 2020).

On the other hand, pesticides are used by most farmers in the MRD to control pests and diseases. Rice yield quality and competitiveness are low due to limited and scattered production. To accommodate this recent situation, an increase in rice quality is required. Many businesses now purchase rice for export, albeit in small quantities compared to the MRD's rice production. To increase the economic value of rice, Vietnam must concentrate on the areas of production and consumption, allowing farmers to make more money and improve their lives.

While previous studies have looked at the economic value of the rice value chain without making comparisons or using a qualitative approach to analyze coordination, quantitative data and comparison of vertical and horizontal coordination have revealed little about the rice value chain. As a result, more research is required to understand the value chain's benefits and drawbacks to understand better the current stakeholders involved. The results of this study will help the Vietnamese government and policymakers issue future governance and policy implications. Therefore, to improve the value of high-quality rice in the value chain, promote acreage expansion, and improve economic efficiency for each household, this study first maps and estimates the additional weight and benefits of stakeholders involved in the value chain stratified by vertical and horizontal coordination. Policy implications are then drawn from these findings. To date, this is the first study the researchers are aware of that evaluates the rice value chain in MRD Vietnam and compares different linkages using a quantitative dataset. The results of this study can also be used as a foundation for other developing countries to consider when developing agricultural export policies in the future.

\section{LITERATURE REVIEW AND RESEARCH METHODOLOGY}

\subsection{Literature Review}

The value chain is critical in ensuring a diverse and secure global and local agricultural sector worldwide. Horizontal integration is internally coordinated through administrative activity within the business. In comparison, external coordination or vertical integration is accomplished through various actors, including pricing, markets, and other forces that govern relationships between forms. Vertical integration does not include contract manufacturing. Mighell and Jones (1963) assert that "Vertical coordination is a catch-all term that refers to any method of coordinating the vertical stages of production and marketing. Alternative coordination modes include the market-price system, vertical integration, contracting, and cooperation, either alone or in combination".

Nonetheless, the critical nature of coordination enables a thorough understanding of value chain details and potential upgrades. Thus, economic analysis will significantly contribute once it clarifies what is involved and the distinctions between various coordinations. Horizontal coordination benefits producers by increasing economies of scale and reducing transaction costs. On the other hand, vertical connections establish a connection between producers and sellers (Mitchell, Keane, \& Coles, 2009). Trienekens (2011) provides three dimensions for evaluating the value chain in developing countries: constraints, value chain elements, and upgrade potential. Limitations on market access, institutional vacancies, and a scarcity of resources all impede the value chain. Within this value chain, value-added, horizontal, and vertical coordination and governance systems are included.

Additionally, value chain upgrading entails conducting market research, implementing network systems, and completing government forms. Mesquita and Lazzarini (2009) examined collaboration among small- and medium-sized enterprises in Argentina. They discovered both vertical and horizontal benefits to global markets. While vertical integration connects field manufacturing producers, horizontal integration expands access to resources and innovation. As a result, collective action can help improve access to global markets. In recent years, the trend in American agriculture has been toward increased specialization in fewer commodities and stages of production. As a result, 
numerous forms of uncertainty exist, necessitating countermeasures such as collaboration, contracting production, insurance, and various methods of coordination (Mighell \& Jones, 1963).

Additionally, contract farmers benefit from reducing scale bias associated with horizontal and vertical integration in MRD (Ba, de Mey, Thoron, \& Demont, 2019). Coordination in the agricultural sector overcomes disadvantages, improves farmers' market access capabilities, and reduces transaction costs (Min, 2011). Vietnam's central government currently promotes vertical and horizontal coordination through a policy (Ba et al., 2019). Vertical coordination through the ordering of contract relationships between food companies (exporters) and farmers, and horizontal coordination through the "Small Farmers Large Field" program must have involved researching the Vietnamese value chain and its performance and potential upgrade strategies. Vo-Thi and Nguyen (2011); Vo-Thi and Nguyen (2013) and Vo-Thi and Nguyen (2016) conducted value chain analyses of agricultural products, particularly rice, in Can Tho, Soc Trang, Tra Vinh, An Giang, Kien Giang, Long An, and Soc Trang in MRD. The authors of these studies used qualitative analysis methods (Vo-Thi \& Nguyen, 2013), descriptive statistics (Nguyen, 2009; Vo-Thi. \& Nguyen, 2013), a cost-benefit analysis method (Nguyen, 2009; Vo-Thi \& Nguyen, 2013; Vo-Thi et al., 2016), and economic analysis (Nguyen, 2009; Vo-Thi \& Nguyen, 2011), logistics, risk, and commodity chain risk management (Vo-Thi \& Nguyen, 2011; Vo-Thi... et al., 2016), value chain analysis using (Nguyen, 2009; Springer-Heinze, 2018; Vo-Thi et al., 2016), Porter's model of five competitive pressures analysis (Nguyen, 2009), and analysis of the entire rice industry's SWOT analysis (Vo-Thi \& Nguyen, 2011; Vo-Thi \& Nguyen, 2013; Vo-Thi et al., 2016). The authors then discuss the five functions of the economy: input, production, procurement, trade and consumption, market channels in the value chain, domestic and export channels (Nguyen, 2009), and some economic analysis indicators. However, the majority of prior research has concentrated on the conventional value chain. The added value of the entire sector is low and distributed among many actors (including the domestic rice value chain and the export rice value chain). However, rice farmers earn the second-highest profit per kilogram of rice produced (25.6 percent) after wholesale/retail (34.4\% and 29.9\%) (Vo-Thi \& Nguyen, 2011). Another study conducted in Tra Vinh province discovered that farmers accounted for the highest profit margin, of $66.5 \%$. However, profit per household per year is relatively low (49.4 million VND) because the annual sales volume per household is significantly lower than that of other actors (Vo-Thi et al., 2016).

Additionally, these studies identify risks in this sector, such as weather, climate change, institutional policy, logistics, and post-harvest handling, most notably a lack of chain connectivity and market risk (unstable selling price) (Vo-Thi \& Nguyen, 2011; Vo-Thi et al., 2016). However, previous research limited the use of case studies to illustrate and compare specific quantitative values (Trienekens, 2011). Yet, except for Ba et al. (2019), little attention has been paid to the differences between vertical and horizontal coordination in the rice sector. However, their data are qualitative, and the relationship between vertical and horizontal integration remains unknown. On the other hand, previous research has focused on a single type of coordination or the decision to join contract farming (Ba et al., 2019). As a result, this study maps the current value chain according to the type of coordination. It compares it in both vertical and horizontal coordination. Then, objective information about cooperative as one of linkage-type is also provided. The findings of this study are expected to contribute to emerging value chain literature, mainly through quantitative data analysis and by fostering the rice value chain in MRD. Such actions, in turn, are expected to have significant policy implications for current government policy guidance, as they respond to developments in policy reform and the emerging need for research on evaluating coordination. The study's first contribution comes from economic analysis. It identifies the contents and issues involved in vertical and horizontal coordination. A second way to contribute to the economic benefit of value chain participants is to consider those who are already members of cooperatives and contracting businesses.

\subsection{Research Methodology \\ 2.2.1. Data Collection}

Primary data in the study were collected by directly interviewing 160 rice farmers and 25 chain actors in Hau Giang province, one of the typical rice production areas in MRD, through a random sampling method based on the list of farmers provided by the local government. Secondary data used was collected from the local Statistical Department, Statistical Yearbook, and the local Department of Agriculture and Rural Development.

The observations were then stratified based on horizontal and vertical coordination. While horizontal linkages are the connection between farmers and those who participate in cooperatives, vertical linkages are represented by farmers who hold contracts with firms. Through a survey of 160 rice farmers in a research area, 107 households participate in cooperatives, accounting for $66.9 \%$, and 53 households do not participate in cooperatives, accounting for $33.1 \%$. For households participating in vertical linkage, 80 households account for $50 \%$ of the total number of households growing high-quality rice in the study area and which have a contract with enterprises, and households not participating in vertical linkage account for $50 \%$.

\subsubsection{Data Analysis Method}

In this research, value chain analysis was employed as a descriptive means to understand how current vertical and horizontal coordination moves and improves value chains. The value chain approach (Springer-Heinze, 2018) of GTZ (Deutsche Gesellschaft Für Technische Zusammenarbeit, Germany) was employed. From this framework, the value chain was analyzed based on providing inputs to the final product, including preliminary processing, transportation, marketing (if any), and finally selling the product to consumers. Further detailed discussion about vertical and horizontal coordination within the agricultural value chain can be found in Mighell and Jones (1963); Vroegindewey (2015); Ba et al. (2019) and Min (2011). This study, therefore, expects to contribute to detailed frameworks for analyzing coordination in agricultural value chains, especially in developing countries. 
In order to seek subjective information from farm households as the main stakeholder in the value chain, the binary Logit model was then employed to estimate the probability of farmers' decision to join the cooperatives as one kind of linkage. The dependent variable $\mathrm{Y}$ takes two values, 1 or $\mathrm{O}$ (with 1 is the desire to join the cooperative, $\mathrm{O}$ is vice versa). $\mathrm{X}_{\mathrm{i}}$ is the factor influencing the decision to join the cooperative. The general form of the binary Logit model is as follows:

$$
\operatorname{Ln}\left[\frac{P(Y=1)}{P(Y=0)}\right]=\beta+\beta_{1} \mathrm{X}_{1}+\beta_{2} \mathrm{X}_{2}+\beta_{3} \mathrm{X}_{3}+\beta_{4} \mathrm{X}_{4}+\ldots . .+\beta_{\mathrm{n}} \mathrm{X}_{\mathrm{n}}
$$

Where $\mathrm{P}(\mathrm{Y}=1)=\mathrm{P}_{0}$ is the probability that the household wishes to join or continue to participate in agricultural cooperatives; $\mathrm{P}(\mathrm{Y}=0)=1-\mathrm{P}_{0}$ is the probability that the household does not want to participate or not want to continue to join the agricultural cooperatives; $\beta$ is constant and $\beta_{1}$ to $\beta_{9}$ are estimated coefficients; and $\operatorname{Ln}$ is the log to base $e$ $(\mathrm{e}=2.714) . \mathrm{X}_{1}$ to $\mathrm{X}_{9}$ are the independent variables, including factors affecting the decision to join the cooperative. Specifically, $\mathrm{X}_{1}$ (age) is the age of household head (years) (Xiang \& Sumelius, 2010), $\mathrm{X}_{2}$ (gender) is the gender of household head (male $=0$, female $=1$ ) (Atmis, Günşen, Lise, \& Lise, 2009), $\mathrm{X}_{3}$ (experience) is the farming experience of the household head (years) (Awotide, 2012), $\mathrm{X}_{4}$ (education level) is the number of years in the school of the household head (year) (Awotide, 2012), $\mathrm{X}_{5}$ (area) is the total area of agricultural land $\left(1,000 \mathrm{~m}^{2}\right)$ (Zheng, Wang, \& Song, 2011 ; Zheng, Wang, \& Awokuse, 2012), $\mathrm{X}_{6}$ (training participation) takes 1 if participating and $\mathrm{O}$ if not participating), $\mathrm{X}_{7}$ (farmer union participation) with 1 if participating and $\mathrm{o}$ if not participating) (Zheng et al., 2011; Zheng et al., 2012), $\mathrm{X}_{8}$ (income) is households' annual income, and $\mathrm{X}_{9}$ (perception of benefit) is the households' expectation about benefits obtained when participating in agricultural cooperatives ( 5 points Likert scale from 1 - very unimportant to 5 - very important).

In addition, SWOT analysis was employed to recognize the advantages (strengths) and difficulties (weaknesses) as well as opportunities and threats/challenges of each actor participating in the chain. It was also employed to understand the whole industry (product) and from which they propose solutions to increase the value of the chain. This information was obtained through focus group discussions (FGDs) with local experts from the Department of Agriculture and Rural Development, typical local farmers, and representatives of cooperatives in Hau Giang province based on an open-ended questionnaire about sustainable rice value chain concepts. The information was then grouped into internal factors (weaknesses and strengths) and external factors (opportunities and threats). This information was then considered by experts (lecturers and researchers) from the School of Economics at Can Tho University through a further focus group discussion.

\section{RESULTS AND DISCUSSION}

\subsection{Economic Performance Indicators Stratified by Type of Linkages}

Production costs are an essential factor in determining the economic performance of farmers producing rice. The cost of production includes input costs, machinery, hired labor, house labor, and bank loan interest (Table 1).

Table 1. Rice production cost category stratified by linkages type.

\begin{tabular}{|c|c|c|c|c|c|c|}
\hline \multirow[t]{3}{*}{ Category } & \multirow[t]{3}{*}{ Details } & \multicolumn{4}{|c|}{ Paddy production cost per $1 \mathrm{~kg}\left(\mathrm{US} \$^{1 / \mathrm{kg}}\right)$} & \multirow{3}{*}{ Mean } \\
\hline & & \multicolumn{2}{|c|}{ Horizontal coordination } & \multicolumn{2}{|c|}{ Vertical coordination } & \\
\hline & & $\begin{array}{c}\text { Non-cooperative } \\
\text { member farmer } \\
\quad(n=53)\end{array}$ & $\begin{array}{c}\text { Cooperative } \\
\text { member } \\
\text { farmers } \\
(n=107) \\
\end{array}$ & $\begin{array}{c}\text { Non- } \\
\text { contracting } \\
\text { farmer } \\
(\mathrm{n}=\mathbf{8 0}) \\
\end{array}$ & $\begin{array}{c}\text { Contracting } \\
\text { farmer } \\
(n=80)\end{array}$ & \\
\hline Inputs & $\begin{array}{l}\text { Seeds, fertilizer, } \\
\text { pesticides }\end{array}$ & 0.068 & 0.065 & 0.072 & 0.060 & 0.066 \\
\hline \multirow[t]{3}{*}{ Mecha-nism } & Water pumping & 0.006 & 0.005 & 0.006 & 0.004 & 0.005 \\
\hline & Tractor & 0.008 & 0.008 & 0.009 & 0.007 & 0.008 \\
\hline & $\begin{array}{l}\text { Harvesting } \\
\text { machine }\end{array}$ & 0.015 & 0.019 & 0.018 & 0.017 & 0.018 \\
\hline \multicolumn{2}{|l|}{ Hired labor } & 0.004 & 0.005 & 0.004 & 0.005 & 0.004 \\
\hline \multicolumn{2}{|c|}{ Family labor } & 0.032 & 0.021 & 0.031 & 0.018 & 0.024 \\
\hline \multicolumn{2}{|c|}{ Bank interest } & 0.011 & 0.002 & 0.004 & 0.005 & 0.005 \\
\hline \multicolumn{2}{|l|}{ Total } & 0.143 & 0.125 & 0.145 & 0.117 & 0.131 \\
\hline
\end{tabular}

Source: Survey data, 2020

When looking at the mean values of the cost category, the production cost of $1 \mathrm{~kg}$ of rice includes input costs (varieties, fertilizers, pesticides) which account for the highest proportion of 50.6\%. The remaining category, so-called additional costs, accounted for $49.4 \%$ (including water pumping costs of $4.1 \%$, tractor costs $5.9 \%$, harvesting costs $13.7 \%$, and bank interest rate of 3.6\%). Family labor accounted for $18.7 \%$, and spending on hired labor accounted for about $3.4 \%$. On $1 \mathrm{~kg}$ of rice, farmers have two selling prices of US $\$ 0.238 / \mathrm{kg}$ for the food company and US $\$ 0.233 / \mathrm{kg}$ for the traders, with a total production cost of US\$0.131/ $\mathrm{kg}$ and a profit of US\$0.102-0.107/ $\mathrm{kg}$. The total input cost accounted for the largest with US $\$ 0.066$, including seeds, pesticides, and fertilizers. The price increased by US $\$ 0.036$ and the labor cost was US\$0.029 (US\$0.024 for house labor and US $\$ 0.004$ for hired labor). Interestingly, the charge is always lower when participating in vertical (also called contracting farmers) or horizontal coordination (cooperative

${ }^{1}$ US\$1 was equal to 22,890 Vietnamese Dong (VND) on June 30, 2021 
members). When compared between the two kinds of coordination, contracting farmers achieve higher efficiency with lower prices. When participating in contracting, farmers must follow technical guidance from firms.

Table 2. Differences in income sources stratified by linkage type (US $\$ /$ farm-households/year).

\begin{tabular}{|c|c|c|c|c|c|c|}
\hline \multirow[t]{2}{*}{ Income sources } & \multicolumn{3}{|c|}{ Horizontal coordination } & \multicolumn{3}{|c|}{ Vertical coordination } \\
\hline & $\begin{array}{c}\text { Cooperative } \\
\text { member } \\
\text { farmer } \\
(n=107)\end{array}$ & $\begin{array}{c}\text { Non- } \\
\text { cooperative } \\
\text { member } \\
\text { farmer } \\
(\mathrm{n}=53)\end{array}$ & Diff. & $\begin{array}{c}\text { Contracting } \\
\text { farmer } \\
(n=80)\end{array}$ & $\begin{array}{c}\text { Non- } \\
\text { contracting } \\
\text { farm } \\
(n=80)\end{array}$ & Diff. \\
\hline $\begin{array}{l}\text { 1. Income from rice } \\
\text { farming season }\end{array}$ & 9,488 & 6,371 & $3,117^{* * * *}$ & 9,872 & 7,038 & $2,485^{* * * *}$ \\
\hline - Winter-spring & 3,819 & 2,601 & $1,218^{* *}$ & 3,969 & 2,862 & $1,107^{* *}$ \\
\hline - Summer-autumn & 2,826 & 1,918 & $908^{* * * *}$ & 2,923 & 2,127 & $796^{* * * * *}$ \\
\hline - Autumn-winter & 2,843 & 1,852 & $991^{* * * *}$ & 2,980 & 2,049 & $931^{* * * *}$ \\
\hline 2. Non-farm income & 496 & 202 & $294^{*}$ & 517 & 280 & $237^{\mathrm{ns}}$ \\
\hline Total $(1+2)$ & 9,984 & 6,573 & $3,411^{* * * *}$ & 10,389 & 7,318 & $3,072^{* * *}$ \\
\hline
\end{tabular}

Source: Survey data, 2020

As indicated in Table 2, farmers who participate in vertical or horizontal linkages obtain higher income than other groups. The differences were statistically significant at $5 \%$ in the winter-spring season. In contrast, in the summerautumn and autumn-winter seasons, differences were statistically significant at the $1 \%$ level. The aggregate total income reveals a higher income in the vertical coordination group. Companies usually offer contracting farmers higher rice selling prices, and therefore, they receive a higher income from rice farming. Interestingly, a comparison between non-farm income shows a higher number of farmers in coordination. Nevertheless, they are significantly different in vertical linkages. In coordination linkages, a $10 \%$ level of significance indifference was noted. In other words, involving non-farm income in the analysis showed that participation in associations could significantly improve farmers' income.

\subsection{Rice Value Chain Analysis}

3.2.1. Horizontal Coordination Value Chain versus Conventional Coordination

Figure 1 illustrates horizontal linkages and the conventional rice value chain diagram with the next chain actors (with and without cooperative membership, which is the key indicator for stratifying farmers), traders, processors (drying, milling, polishing), food companies, and retailers.

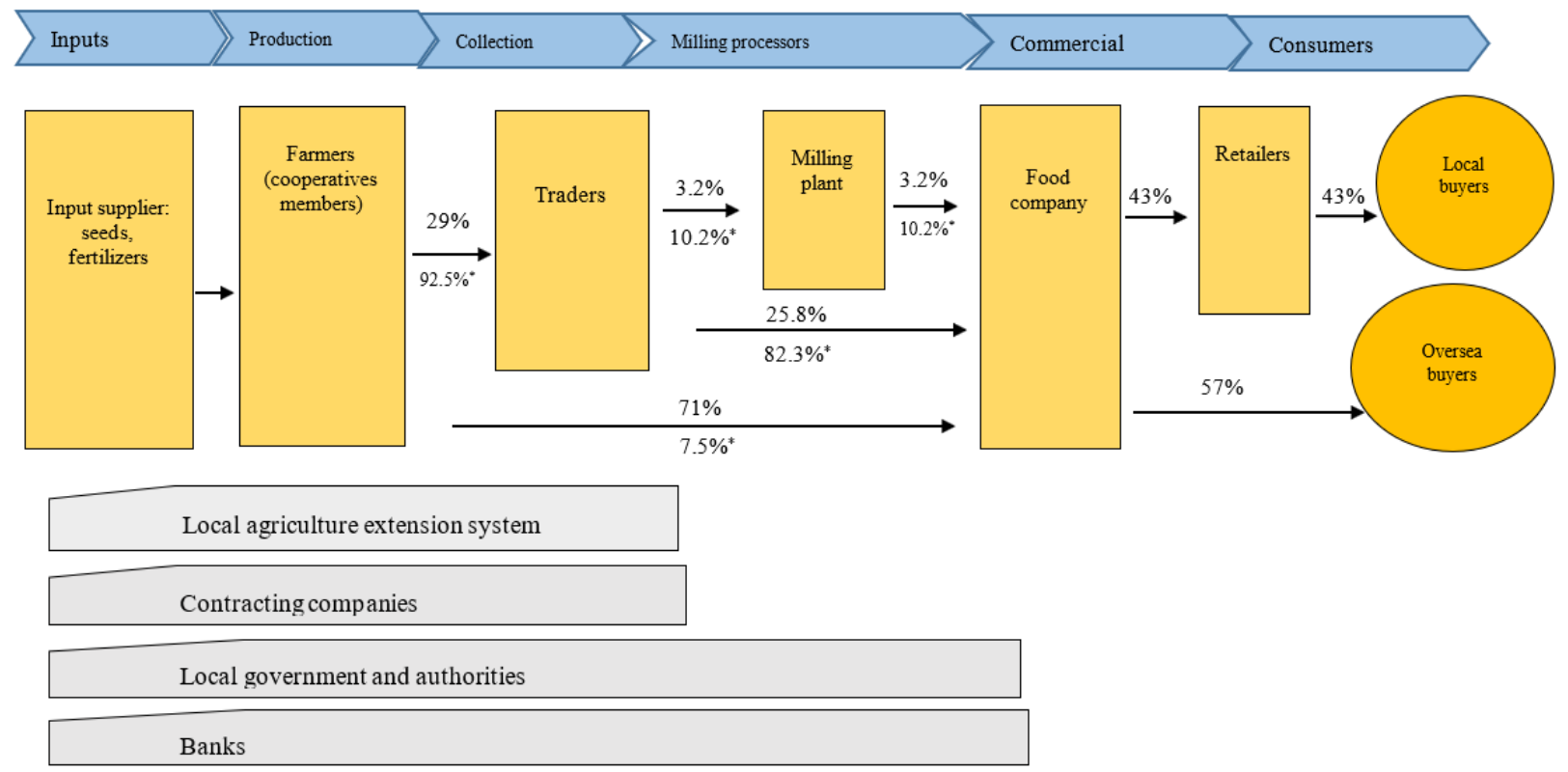

Figure 1. Horizontal linkages versus conventional chain diagram.

Note: * indicates the proportion in the conventional chain (including farmers are not cooperative members).

Source: Survey data, 2020 .

\subsubsection{Horizontal Coordination Market Channel (Coded as Channels 1, 2, and 3)}

The value chain for horizontal coordination includes farmers participating in cooperatives, traders, millers, food companies, and retailers. Farmers perform the production function. The collection function is performed by traders who buy $29.0 \%$ of the total output from farmers. Two actors that serve the processing functions are the miller and the food company. Retailers are important commercial actors in the value chain, bringing $43.0 \%$ of the total chain output to the domestic market. The food company, besides selling to retail agents, also exports with a proportion of $57.0 \%$. 
Channel 1: Cooperatives member farmers $\rightarrow$ Traders $\rightarrow$ Milling plants $\rightarrow$ Food companies $\rightarrow$ Retailers

Channel 2: Cooperatives member farmers $\rightarrow$ Traders $\rightarrow$ Food companies $\rightarrow$ Retailers

Channel 3: Cooperatives member farmers $\rightarrow$ Food companies $\rightarrow$ Retailers

In this distribution chain, farmers sell rice through cooperatives as their representative partners to food companies, accounting for $71.0 \%$ of the chain's total rice production. However, several of them currently have to trade with traders since the paddy quality does not meet the contract requirements, or they would like to receive payment immediately. In contrast, the revenue from food companies usually arrives after two weeks. In some cases, traders offer them better prices because of their competitiveness. Therefore, $29.0 \%$ of the total rice volume was sold to traders. Then, traders sell rice to food companies and milling plants, accounting for $25.8 \%$ and $3.2 \%$ of the total output, respectively. Next, the milling plant sells rice to the food company for $3.2 \%$. After receiving rice from farmers and milling plants and completing the processing stages, the food company distributes $43 \%$ of the total output to retailers. After that, the agent sells it to the consumer, and the rest of the food companies export it to overseas markets.

\subsubsection{Non-horizontal Coordination Value Chain (Coded as Channels 4, 5, and 6) \\ Channel 4: Farmers not participating in cooperatives $\rightarrow$ Traders $\rightarrow$ Milling plants $\rightarrow$ Food companies $\rightarrow$ Retailers \\ Channel 5: Farmers not participating in cooperatives $\rightarrow$ Traders $\rightarrow$ Food companies $\rightarrow$ Retailers \\ Channel 6: Farmers do not join cooperatives $\rightarrow$ Food companies $\rightarrow$ Retailers}

Farmers who do not join cooperatives through traders to supply rice to the company account for $92.5 \%$ of the total rice volume of the whole channel (Channel 4). Some can produce better-quality rice and then sell it directly to food companies (7.5\%) (Channel 6). After that, traders sell rice to milling plants, accounting for $10.2 \%$ of the total output (Channel 4) and $82.3 \%$ to food companies (Channel 5). Next, the milling plant sells rice to the food company for $10.2 \%$. The food company distributes it to the retailers for $43 \%$ of the total output. The retailers then sell it to the consumer.

Besides the above-mentioned stakeholders, coordination facilitators in the value chain include local agriculture extension systems, contracting firms, local governments and authorities, and banks. Although these functions should be in some necessary forms, such as pushing or subsidies to coordination, increasing payoffs from coordination, and increasing belief in incoordination. However, due to limited resources, these functions have never been fulfilled.

\subsubsection{Vertical Coordination Versus Conventional Channel Value Chain}

The vertical linkage and traditional channel are shown in Figure 2 with the following key actors: farmers, traders, processors (drying, milling, polishing), food companies, and retailers.
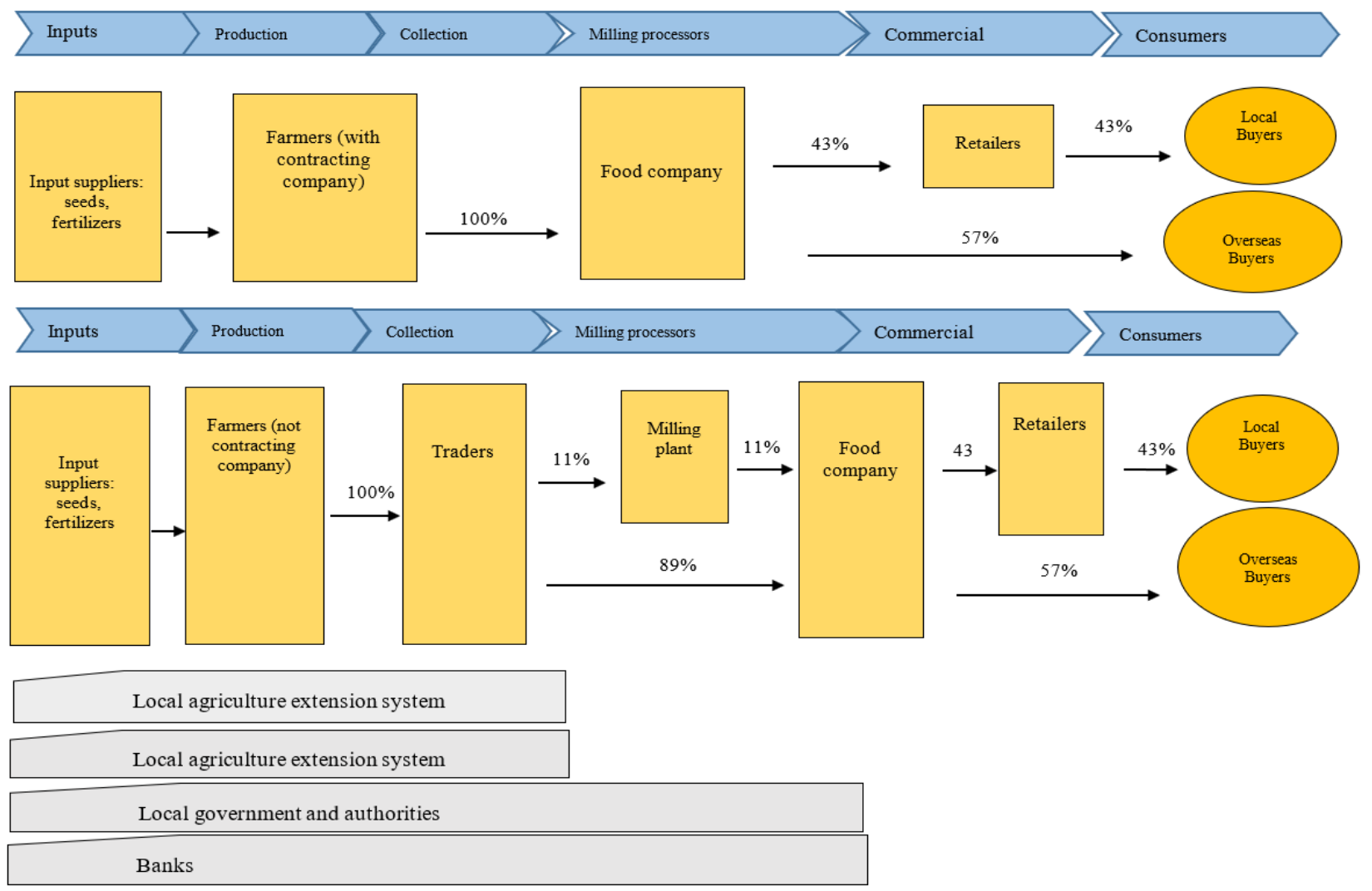

Source: Survey data, 2020 .

Figure 2. Vertical coordination versus conventional channel rice value chain.

3.2.3.1. Vertical Coordination Value Chain (Coded as Channel 7)

Channel 7: Farmers $\rightarrow$ Food companies $\rightarrow$ Retailers 
Farmers who have signed a contract to sell rice to food companies directly sell $100 \%$ rice output through this distribution channel. Following the collection of rice from farmers, it is transported to the company's factories for processing. After the rice has been processed, the food company distributes it to retailers. 53\% is accounted for by retailers, while the remainder is accounted for by food companies exporting to foreign markets. However, not all written contracts have been made in this type of coordination. As a result, some farmers violate their commitments and sell products to traders if they are not paid promptly or if the paddy quality does not meet the company's specifications.

\subsubsection{Non-Vertical Coordination Value Chain (Coded as Channels 8 and 9)}

Channel 8: Farmers $\rightarrow$ Traders $\rightarrow$ Milling Plants $\rightarrow$ Food Companies $\rightarrow$ Retailers

Channel 9: Farmers $\rightarrow$ Traders $\rightarrow$ Food companies $\rightarrow$ Retailers

Non-contracting farmers supply rice to the company via traders, accounting for $100 \%$ of the channel's total rice volume. Following that, traders transport rice to milling plants and food companies, accounting for $11 \%$ output (Channel 8) and $89 \%$ output (Channel 9), respectively. Next, milling plants sell rice to the food company for $11 \%$. The food company redistributes to the retailers $43 \%$ of the total output. And after that, retailers sell it to the end consumer.

\subsection{Economic Analysis of Rice Value Chain}

3.3.1. Economic Analysis of Value Chains Stratified by Horizontal Coordination

Determining the net added value of each actor when participating in the chain is essential. There are six channels when comparing horizontal linkages and non-horizontal coordination (conventional chain). The $1^{\text {st }}$ and $4^{\text {th }}$ channels are the main channels where all the actors are involved in the chain (Table 3).

Table 3. Value-added analysis by market channel of horizontal coordination chains (US $\$ / \mathrm{kg}$ ).

\begin{tabular}{|c|c|c|c|c|c|c|}
\hline \multirow{2}{*}{\multicolumn{7}{|c|}{\begin{tabular}{l|l} 
Category & Farmers \\
Horizontal coordination &
\end{tabular}}} \\
\hline & & & & & & \\
\hline \multicolumn{7}{|c|}{ Channel 1: Cooperatives' member farmers $\rightarrow$ Traders $\rightarrow$ Milling plants $\rightarrow$ Food companies $\rightarrow$ Retailers } \\
\hline Selling price & 0.296 & 0.324 & 0.400 & 0.677 & 0.791 & \\
\hline Intermediary cost & 0.099 & 0.296 & 0.324 & 0.400 & 0.677 & \\
\hline Added value & 0.090 & 0.011 & 0.024 & 0.203 & 0.076 & \\
\hline Net added value & 0.107 & 0.017 & 0.053 & 0.074 & 0.037 & 0.288 \\
\hline$\%$ net added value & 37.1 & 6.0 & 18.3 & 25.7 & 12.9 & 100 \\
\hline \multicolumn{7}{|c|}{ Channel 2: Cooperatives' member farmers $\rightarrow$ Traders $\rightarrow$ Food companies $\rightarrow$ Retailers } \\
\hline Selling price & 0.296 & 0.330 & $\mathrm{x}$ & 0.677 & 0.791 & \\
\hline Intermediary cost & 0.099 & 0.296 & $\mathrm{x}$ & 0.330 & 0.677 & \\
\hline Added value & 0.090 & 0.011 & $\mathrm{x}$ & 0.273 & 0.076 & \\
\hline Net added value & 0.107 & 0.023 & $\mathrm{x}$ & 0.074 & 0.037 & 0.241 \\
\hline$\%$ net added value & 44.4 & 9.5 & $\mathrm{x}$ & 30.7 & 15.4 & 100 \\
\hline \multicolumn{7}{|c|}{ Channel 3: Cooperatives' member farmers $\rightarrow$ Food companies $\rightarrow$ Retailers } \\
\hline Selling price & 0.309 & $\mathrm{x}$ & $\mathrm{x}$ & 0.677 & 0.791 & \\
\hline Intermediary cost & 0.099 & $\mathrm{x}$ & $\mathrm{x}$ & 0.309 & 0.677 & \\
\hline Added value & 0.090 & $\mathrm{x}$ & $\mathrm{x}$ & 0.295 & 0.076 & \\
\hline Net added value & 0.119 & $\mathrm{x}$ & $\mathrm{x}$ & 0.074 & 0.037 & 0.231 \\
\hline$\%$ net added value & 51.8 & $\mathrm{x}$ & $\mathrm{x}$ & 32.1 & 16.1 & 100 \\
\hline \multicolumn{7}{|c|}{ Conventional channels } \\
\hline \multicolumn{7}{|c|}{ Channel 4: $\quad$ Farmers not in cooperatives $\rightarrow$ Traders $\rightarrow$ Milling plants $\rightarrow$ Food companies $\rightarrow$ Retailers } \\
\hline Selling price & 0.298 & 0.324 & 0.000 & 0.677 & 0.791 & \\
\hline Intermediary cost & 0.104 & 0.298 & 0.000 & 0.400 & 0.677 & \\
\hline Added value & 0.114 & 0.011 & 0.024 & 0.203 & 0.076 & \\
\hline Net added value & 0.080 & 0.016 & 0.000 & 0.074 & 0.037 & 0.260 \\
\hline$\%$ net added value & 30.9 & 6.1 & 20.2 & 28.5 & 14.3 & 100 \\
\hline \multicolumn{7}{|c|}{ Channel 5: Farmers not in cooperatives $\rightarrow$ Traders $\quad \rightarrow$ Food companies $\rightarrow$ Retailers } \\
\hline Selling price & 0.298 & 0.330 & $\mathrm{x}$ & 0.677 & 0.791 & \\
\hline Intermediary cost & 0.104 & 0.298 & $\mathrm{x}$ & 0.330 & 0.677 & \\
\hline Added value & 0.114 & 0.011 & $\mathrm{x}$ & 0.273 & 0.076 & \\
\hline Net added value & 0.080 & 0.021 & $\mathrm{x}$ & 0.074 & 0.037 & 0.213 \\
\hline$\%$ net added value & 37.7 & 10.1 & $\mathrm{x}$ & 34.8 & 17.4 & 100 \\
\hline \multicolumn{7}{|c|}{ Channel 6: Farmers do not join cooperatives $\rightarrow$ Food companies $\rightarrow$ Retailers } \\
\hline Selling price & 0.317 & $\mathrm{x}$ & $\mathrm{x}$ & 0.677 & 0.791 & \\
\hline Intermediary cost & 0.104 & $\mathrm{x}$ & $\mathrm{x}$ & 0.317 & 0.677 & \\
\hline Added value & 0.114 & $\mathrm{x}$ & $\mathrm{x}$ & 0.286 & 0.076 & \\
\hline Net added value & 0.100 & $\mathrm{x}$ & $\mathrm{x}$ & 0.074 & 0.037 & 0.211 \\
\hline$\%$ net added value & 47.3 & $\mathrm{x}$ & $\mathrm{x}$ & 35.1 & 17.6 & 100 \\
\hline
\end{tabular}


Rice farmers: The findings indicate that farmers have the highest net added value across all six channels. Farmers who sell rice to food companies through cooperatives $(0.309 / \mathrm{kg})$ receive a higher price than those who sell rice to traders (US\$0.296/kg). Farmers who join cooperatives incur a total cost of US $\$ 0.189 / \mathrm{kg}$ (intermediary cost + additional cost) but earn a substantial profit of US\$0.119/kg. As a result, Channel three should be prioritized for further development in the long term to upgrade linkages.

Farmers who do not participate in cooperatives receive a lower price for rice sold to traders $(\mathrm{US} \$ 0.298 / \mathrm{kg})$ than cooperative members (US $\$ 0.317 / \mathrm{kg}$ ). Farmers who do not join cooperatives incur the same total cost of US $\$ 0.217 / \mathrm{kg}$ (intermediary cost + additional cost) but earn a higher profit of US\$0.096/kg if they sell their product to a food company. Thus, among conventional channels, Channel six should prioritize upgrading to establish business connections necessary for long-term production and consumption stability. Keep in mind that food companies only purchase from farmers who are not cooperative members when they need to meet demand and maintain a certain level of quality. As a result, only a small number of farmers were able to sell their products to them.

Traders: At this point, this actor is crucial, as many farmers are not cooperative members for various reasons. Traders sell rice to milling plants and food companies for US\$0.324 and $0.330 / \mathrm{kg}$, respectively. They have the lowest net added value in the value chain.

Food company: The company obtains raw materials from various sources (traders, farmers), with varying purchasing prices. However, when purchasing rice from traders and milling plants, the company runs the risk of incurring additional costs if the rice does not meet production standards, resulting in loss and additional costs, as opposed to purchasing rice from cooperatives or farmers who may enter into a contract for loss and purchase. Food companies, on average, achieve the second-highest net added value.

Retailers: Retailers are exclusive participants in the domestic rice consumption chain. The chain's actors purchase their products exclusively from a food company, which sells them for an average of US $\$ 0.677 / \mathrm{kg}$. After deducting agency costs, they earn US $\$ 0.037 / \mathrm{kg}$ profit and have a net added value of $12.9 \%, 15.4 \%$, and $16.1 \%$ in the three horizontal linkages, respectively. The net added value varies between $7 \%$ and $18 \%$ in the three conventional channels that are not connected with resellers.

Milling plant: The miller appears on channels one and four. Milling plants purchase rice from traders for US $\$ 0.324 / \mathrm{kg}$, mill it, process it, package it, and sell it to a food company for US $\$ 0.400 / \mathrm{kg}$, earning a profit of US $\$ 0.053 / \mathrm{kg}$. The milling plant's net added value on channels one and four is $18.3 \%$ and $20.5 \%$, respectively.

\subsubsection{Economic Analysis of Value Chains by Vertical Coordination}

Vertical coordination is illustrated by three channels only. Among them, only Channel 8 includes all the actors in the value chain (Table 4).

Table 4. Analysis of value added by market channel of vertical coordination (US $\$ / \mathrm{kg}$ ).

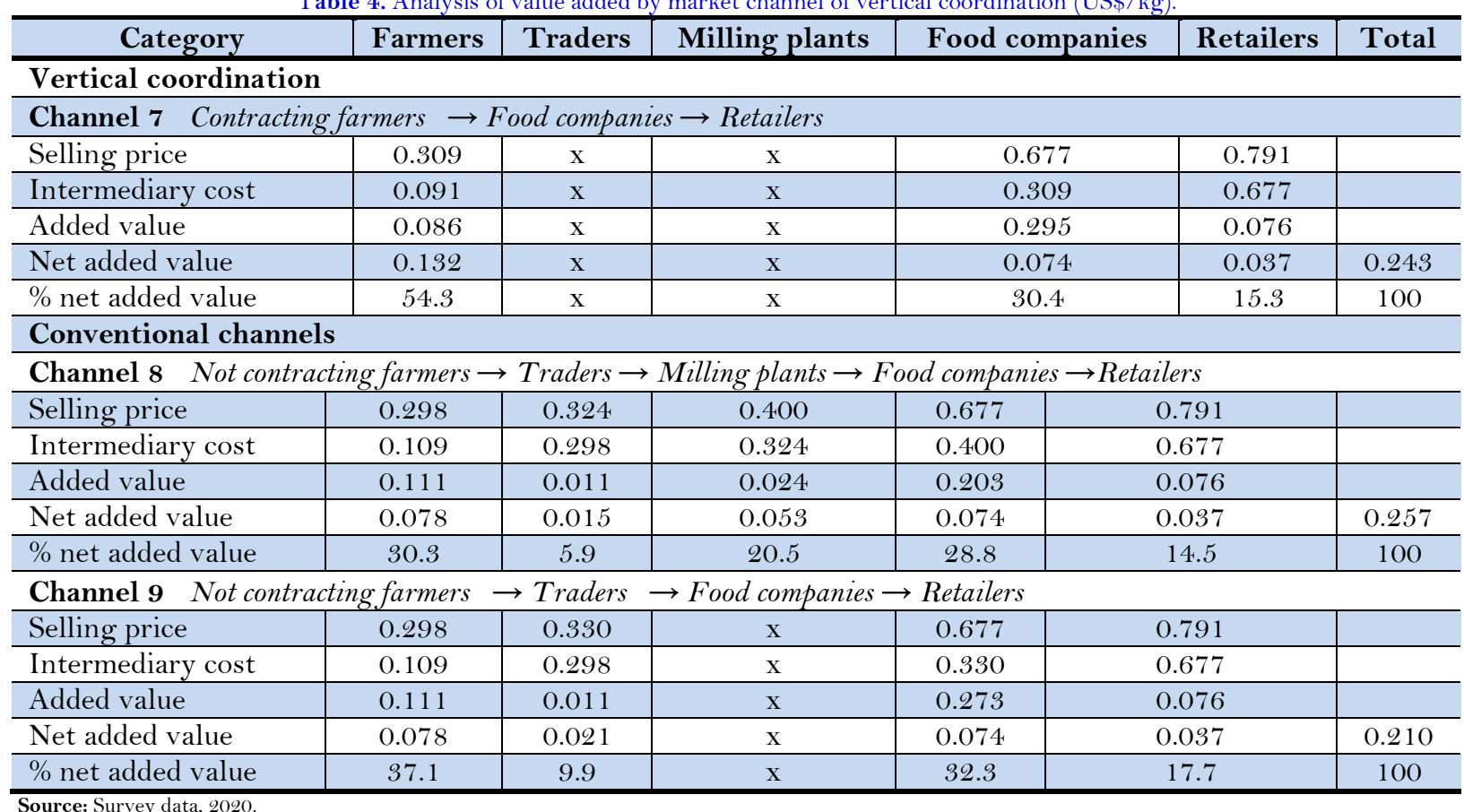

Rice farmers: Once again, the analysis results indicate that farmers are the actors with the highest net value added across all three channels. Farmers who participate in vertical linkages and sell rice to food companies for US $\$ 0.309 / \mathrm{kg}$ earn a higher price than those who do not participate in vertical linkages and sell rice to traders for US $\$ 0.298 / \mathrm{kg}$. Farmers participate in vertical association at a cost of US\$0.177/ kg (intermediary cost + additional cost), earning a high profit of US $\$ 0.132 / \mathrm{kg}$ and a $54.3 \%$ share of the net added value. As a result, Channel seven should prioritize upgrading to establish business relationships that will enable stable and sustainable production and consumption in the long run, consistent with market requirements. 
When farmers sell rice to traders (US\$0.298/ kg), they receive a lower price than farmers who engage in vertical relationships with food companies (US\$0.309/ kg). They spent exactly US $\$ 0.220 / \mathrm{kg}$ (intermediary cost + additional cost). They earned a small profit of US $\$ 0.078 / \mathrm{kg}$, with the net added value of channels seven and eight being $30.3 \%$ and $37.1 \%$, respectively.

Traders: This actor appears in two channels once more. Traders sell rice to milling plants and food companies for US $\$ 0.324 / \mathrm{kg}$ and US $\$ 0.330 / \mathrm{kg}$, respectively, with an additional cost of US\$0.011/ $\mathrm{kg}$, with the lowest net percent added value.

Food company: When purchasing rice from traders and milling plants, the company runs the risk of incurring additional costs if the rice does not meet production standards, resulting in loss and other expenses, as opposed to purchasing rice from farmers who have entered into a purchase contract. Food companies, on average, achieve the second-highest net value-added.

Retailers: This actor joins the chain solely to consume rice in the domestic market. Only one actor, a food company, purchases the products of the chain's actors at an average price of US\$0.677/ $\mathrm{kg}$. They earn US\$0.037/ $\mathrm{kg}$ profit after agency costs and have a $15.3 \%$ added value on channel seven. $14.5 \%$ and $17.7 \%$, respectively, on Channels eight and nine.

Milling plant: This actor purchases rice from traders for US\$0.324/ $\mathrm{kg}$, mills, processes, packs it, and then sells it to a food company for US $\$ 0.400 / \mathrm{kg}$, earning US $\$ 0.053 / \mathrm{kg}$ in profit. Net added value as a percentage of total value is approximately $20.5 \%$.

In summary, the findings of this study are consistent with previous research indicating the need for a significant selling price premium over conventional. Payments should be made on time to encourage a higher participation rate (Ochieng, Veettil, \& Qaim, 2017). Risk-sharing commitments benefit the enterprise by increasing loyalty and participation rates.

Although vertical linkages strengthen relationships between producers and sellers, farmers continue to sell their products to others because the contract price is lower and only verbal contractual commitments are made. This finding is relevant to the weaknesses identified in other developing country value chains (Mitchell et al., 2009). Additionally, the study discovered that enterprises benefit more from this value chain. This study supports the notion that providing these benefits to businesses will increase chain engagement.

\subsection{Chain Logistics, Risk, and Related Policy Analysis \\ 3.4.1. Chain Logistics Analysis}

The findings indicate that as cooperatives and food companies become more integrated into the value chain, it becomes easier for farmers to produce, stabilize their output, and expand market access. For instance, Loc Troi Group was the first private company to establish a rice value chain through high-quality seeds and collaboration with local farmers. Currently, this chain produces 45 thousand tons of rice seeds per year to supply the industry. In 2015 , at an international rice competition featuring 25 varieties of delectable rice from international rice companies, the rice product "Pearl of Heaven-Thien Long" from the Loc Troi AGPPS103 variety won the top three awards for the world's best rice. The success of Loc Troi has facilitated a shift in perspective, created a large sample field for agricultural production, increased productivity and product quality, and established a new image for Vietnamese rice products. Many farmers, on the other hand, are unfamiliar with market-linked production models. The linkages between farmers (horizontal linkages) and between farmers and enterprises (vertical linkages) are insignificant in scale, frail, and unstable. The linkages' internal resource mobilization is still limited. Additionally, the purchasing system is still dependent on small-scale farmers and remote traders, resulting in heterogeneous products and making brand building difficult. Processing technology has fallen short of meeting the requirements for processing and deep processing rice products for specific market segments, most notably the premium rice market.

\subsubsection{Risk Analysis}

According to FGDs with local experts, actors continue to face three major risks when engaging in the current rice chain: market risk, climate change risk, and export policies and institutions risk. These factors have a significant impact on the chain's performance. Additionally, previous research has revealed that weather, agricultural productivity, commodity pricing and availability, market demand, supply- and demand-side regulations, and contract enforcement can all contribute to uncertainty (Barrett et al., 2012; Bijman, 2008).

Market risk: Market mechanisms have a profound effect on all actors along the value chain. Farmers and food companies are the two actors most directly involved in this risk. This risk category includes price fluctuation, product quantity, product quality, and seed type. According to General Statistics Office (2020), up to 50\% of rice production is exported. While MRD rice production currently meets food security requirements, international markets are significant. Contracts will be affected if some actors violate the agreement by failing to follow technique guidance or selling to local traders. They cannot provide sufficient capital for payment and reinvestment.

Climate change risks: Unstable weather conditions also significantly impact the yield and quality of rice products produced. The weather in the MRD can become scorching, with the dry season extremely hot and dry, and salinity intrusion has spread further into the hinterland (Khong et al., 2018; Khong, Loch, \& Young, 2019; Khong et al., 2020). According to the local Department of Agriculture and Rural Development, the highest salinity concentration infiltrating the survey area was $4.2 \%$ (February 11, 2020); in some locations, the highest salinity concentration measured was $18.3 \%$ (April 7, 2020). During the rainy season it rained heavily, resulting in continuous losses during the sowing stage. Prices fell significantly until harvest, forcing people to hire manual cutting labor at a higher cost 
than machine cutting. High humidity results in moldy rice, which causes more damage than self-germination before harvesting, as well as a decrease in selling price.

Risks due to export policies and institutions: This is a critical factor in determining the activities of chain actors. Food security regulations and export policies have a direct impact on the rice chain and, except for the Philippines, the significant and traditional rice import markets of China, Indonesia, and Bangladesh all reduced imports for a variety of reasons, including a shortage of rice due to high stockpiles in China, an election year in Indonesia, and the resumption of production following floods in Bangladesh. Any minor changes in other countries will affect the domestic market to a lesser extent. Simultaneously, food companies must have a large scale and a reliable source of raw materials to meet the requirements for rice export quality. As a result, this is a high-risk policy for food companies in particular and other chain actors in general.

\subsubsection{Analysis of Relevant Policies}

Irrigation and agricultural extension policies have the most significant impact on farmers. Farmers must gradually adapt to climate change by implementing several initiatives such as "Three Reductions, Three Increases", "One Must Do, Five Reductions", "One Must Do Six Reductions", economical watering techniques, and Good Agriculture Practices (GAP) such as VietGAP and GlobalGAP. Numerous large field models have been developed for smallholder farmers to create large production areas linked to enterprises via a contract mechanism. Historically, due to a lack of specific planning and a lack of clear identification of economic, social, and environmental benefits in management, the use of rice husks and straws for inappropriate purposes, such as discharging into canals or burning copper, resulted in negative impacts on the land, water, and air environment, as well as a significant waste of this resource.

The remaining actors, cooperatives, milling plants, and food companies are affected by quality and export policies. At the moment, the majority of exported products are raw, unbranded, and of low competitiveness. In comparison, export turnover typically increases gradually over time. As a result, necessary policies include orienting and supporting farmers and businesses toward quality, and high added value along a sustainable chain; limiting the quantity and export of raw materials progressively; and gradually expanding the area of application of VietGAP, GlobalGAP, or organic in preparation for the development of official export area codes.

Table 5. Binary Logit model results on determinants of farm households' decision to participate in agricultural cooperatives.

\begin{tabular}{|c|c|c|c|c|}
\hline Variables & Marginal effects $(\mathrm{dy} / \mathrm{dx})$ & Std. err. & $P$-value & VIF \\
\hline Age & $-0.000096^{\mathrm{ns}}$ & 0.00019 & 0.676 & 3.34 \\
\hline Gender & $-0.010164^{\mathrm{ns}}$ & 0.01582 & 0.148 & 1.21 \\
\hline Education level & $0.003263^{\mathrm{ns}}$ & 0.00333 & 0.191 & 1.12 \\
\hline Area & $0.000138^{\mathrm{ns}}$ & 0.00025 & 0.599 & 4.33 \\
\hline Income & $-2.78 \mathrm{e}-11^{\mathrm{ns}}$ & 0.00000 & 0.281 & 4.29 \\
\hline Perception of benefit & $0.009934^{* *}$ & 0.00823 & 0.021 & 1.12 \\
\hline Number of obs. & & & & 159 \\
\hline Prob. $>\mathrm{chi}^{2}$ & & & & 0.0065 \\
\hline
\end{tabular}

analysis since one farmer refused to respond to this question.

Source: Survey data, 2020 .

\subsection{Analysis of Farm Household Perception of Participation in Cooperatives}

Table 5 summarizes the results of the binary Logit model employed to identify the determinants of farmers participating in cooperatives. The Pseudo $R^{2}$ of the model is $0.4243(42 \%)$, indicating that the prediction percentage is acceptable. The results reveal that the Variance Inflation Factor (VIF) of the independent variables are all $<5$, implying that there is no multicollinearity in the regression. The Chi-square test value, $0.0065<0.01$, indicates that the model is consistent with the $1 \%$ significance level. Not surprisingly, there are only two factors that have positive influences on households' decision to join cooperatives, including training participation and perception of benefits and consistent with initial expectations. Regarding the benefits of joining a cooperative, the more benefits that come from participating in a cooperative, the higher the proportion of the households that decide to join. Therefore, in order to enhance linkages in the rice value chain sector, the cooperative needs to deliver the benefits they need. In fact, current issues have been observed in both linkages such as financial constraints, inputs quality, training, and market information.

\subsection{SWOT Matrix Analysis}

The SWOT analysis includes the strengths, weaknesses, opportunities, and threats of the entire rice industry chain are shown in Table 6. 
Table 6. SWOT analysis.

\begin{tabular}{|c|c|c|}
\hline SWOT & $\begin{array}{l}\text { Opportunities }(\mathbf{O}) \\
\text { O1: Support policies of the } \\
\text { province and local authorities at } \\
\text { all levels in agricultural } \\
\text { development programs. } \\
\text { O2: The market demand for high- } \\
\text { quality rice varieties is increasing. } \\
\text { O3: Tighten business links with } \\
\text { other food companies. }\end{array}$ & $\begin{array}{l}\text { Threats }(\mathbf{T}) \\
\text { T1: Effects of climate change and } \\
\text { diseases. } \\
\text { T2: Input prices increase. } \\
\text { T3: Technical barriers of difficult } \\
\text { export markets. } \\
\text { T4: Product selling price is not } \\
\text { stable. } \\
\text { T5: New competitive emerging } \\
\text { export countries. }\end{array}$ \\
\hline $\begin{array}{l}\text { Strengths (S) } \\
\text { S1: Farmers have good experience } \\
\text { in rice cultivation. } \\
\text { S2: The land is suitable for some } \\
\text { rice varieties; freshwater is sufficient } \\
\text { for rice cultivation. } \\
\text { S3: Traffic, irrigation, and } \\
\text { mechanization are being invested. } \\
\text { S4: Establishment and restructure } \\
\text { many cooperatives. } \\
\text { S5: The contracting company } \\
\text { provides sufficient input materials } \\
\text { and technical support. }\end{array}$ & $\begin{array}{l}\text { Offensive strategy (SO) } \\
\mathrm{S} 1,2,3,5+\mathrm{O} 1,2 \text { : Convert to high- } \\
\text { quality rice. } \\
\mathrm{S} 3,4+\mathrm{O} 1,3 \text { : Inbound and } \\
\text { outbound logistics. } \\
\mathrm{S} 3,4,5+\mathrm{O} 1,3 \text { : Collective actions } \\
\text { are made. } \\
\mathrm{S} 1,4,5+\mathrm{O} 2 \text { : Diversify products } \\
\text { (herbal rice) and invest in market } \\
\text { strategies. }\end{array}$ & $\begin{array}{l}\text { Coping/adaption strategy (ST) } \\
\text { S1,2,3,4 + T3,4: Technology } \\
\text { development (blockchain). } \\
\text { S4,5 + T5: Improve the capacity and } \\
\text { reputation of cooperatives with } \\
\text { farmers in the chain. } \\
\text { S4,5 + T4,5: Marketing and sales. }\end{array}$ \\
\hline $\begin{array}{l}\text { Weaknesses (W) } \\
\text { W1: Market information is limited } \\
\text { and depends on importing market } \\
\text { (China, Indonesia, and Bangladesh). } \\
\text { W2: Lack of R \& D and written } \\
\text { contract between farmers and food } \\
\text { companies. }\end{array}$ & $\begin{array}{l}\text { Adjustment strategy (WO) } \\
\text { W1,2 + O1,3: Implement } \\
\text { provincial support packages, } \\
\text { projects, programs for key actors, } \\
\text { including food companies. } \\
\text { W 1,2 + O1,2,3: Develop linkages } \\
\text { between different companies to } \\
\text { form nationally operating } \\
\text { companies. }\end{array}$ & $\begin{array}{l}\text { Defensive strategy (WT) } \\
\text { W2 + T3,4,5: Carry out agricultural } \\
\text { extension activities, convert to } \\
\text { organic rice. } \\
\text { W1,2 + T4,5: Producer } \\
\text { collaboration into "Small Farmer } \\
\text { Large Field" (SFLF). }\end{array}$ \\
\hline
\end{tabular}

\section{CONCLUSION AND POLICY IMPLICATIONS}

In summary, the proportion of linked production areas continues to be insufficient. Horizontal linkages, such as cooperatives, have not actively connected production and output seeking and rely heavily on state support. Joining the chain enables farmers to sell rice at a fair price without being pressured, through technical support, output product consumption, profit discounts, and quality assurance output, which have helped farmers increase their profits and reduce their rice production costs. The critical point in the SWOT analysis is that farmers have extensive experience cultivating rice, have production connections, and have participated in numerous new technical training courses. The shortcomings are that the link between farmers and cooperatives, and farmers and food companies, remains tenuous. Farmers have not correctly applied cooperatives' and affiliated companies' techniques and processes. Additionally, farmers are impacted by the weather due to climate change and saline intrusion, reducing rice yield and quality and reducing farmers' competitiveness in the market. Thus, the preferred method of upgrading the chain is to strengthen and develop business ties, which are critical for the long-term stabilization and sustainability of the province's rice industry.

The research findings indicate that the contemporary high-quality rice value chain differs from the traditional chain in several ways. Farmers' profits increase as the number of actors in the chain decreases. They account for a more significant share of the highest net added value. The economic analysis demonstrates that when the economy of the entire chain is analyzed, the actors in the chain, particularly the food companies, have a relatively high economic efficiency. This analysis is critical as a basis for businesses to join the farmer association. However, this value chain continues to face obstacles such as contract terminations and quality concerns. Thus, to advance and complete the rice value chain in a new direction, it is necessary to establish and perfect a new type of cooperative to serve as a link between production and consumption. Moreover, training and sufficient information should also be provided as regression results indicated.

Additionally, it requires the support of credit institutions to ensure that farmers have access to production capital and participating enterprises have access to business capital. Both vertical and horizontal linkages, this research indicates, can be effective tools for upgrading the existing value chain in developing countries, thereby increasing market access, competitiveness, and sustainability of the rice value chain. The study findings confirm that vertical coordination is possible through the development of horizontal coordination and emphasize the critical role of horizontal coordination. In Vietnam, cooperatives enable small farmers to enter into contracts with businesses, increasing confidence in both parties. Enhancing the role of cooperatives and encouraging food firms to participate in the value chain may reduce the government's budget. However, participation in the chain by third-party facilitators such as banks and local governments helps secure firms' capital and provides financial support to small farmers. 
Although Vietnam is one of the top five exporters of rice globally, the traditional rice value chain in Vietnam is primarily focused on increasing quantity. Simultaneously, quality has been neglected despite the market's insufficient demand for rice. However, to capitalize on the opportunity to increase export output and economic value, the rice value chain must be scientifically organized to meet market demand. The findings of this study are corroborated by prior research conducted in China (Min, 2011). Cooperatives have a strong bias for coordination and integration. The more participation and governance are combined into coordination, the more robust and sustainable the linkages become. This research argues that by adopting a cooperative-style government structure, vertical and horizontal coordination can be enhanced. On both fronts, farmer organizations contribute significantly to the development of a value chain. This finding is significant in light of the rapid growth of cooperatives in MRD. However, as previously demonstrated, cooperatives should be treated as private businesses, with government intervention limited to financial assistance and without control (Hussi, Murphy, Lindberg, \& Brenneman, 1993). By examining a case study in Vietnam's MRD, this study demonstrates the critical role of vertical and horizontal coordination in connecting farmers to the market and overcoming constraints. Collective action is required, including top-down policies implemented by contracting firms and bottom-up policies implemented by cooperatives.

By analyzing the value chain using novel concepts, this research expands the quantitative dataset set to explore further and develop the value chain. By describing the value-added chain in detail, the results may aid policymakers and domestic and international firms in developing new activities that will enable them to succeed in agricultural chain investment. In the long run, more specialization and fewer stages in the value chain of each farm product are required, similar to what is required in other developed countries, such as the United States, as well as the contracting of agricultural insurance and the use of various coordinating methods. However, as mentioned previously, certain critical activities must be prioritized in the case of developing countries. This paper will contribute to further coordination, integration, and the implications of structural transformation in agriculture in the developing world.

Funding: This research is funded by the Vietnam Ministry of Education and Training (Grant
number: B2020-TCT-05).
Competing Interests: The author declares that there are no conflicts of interests regarding the
publication of this paper.
Views and opinions expressed in this study are those of the authors views; the Asian Journal of
Agriculture and Rural Development shall not be responsible or answerable for any loss, damage,
or liability, etc. caused in relation to/arising out of the use of the content.

\section{REFERENCES}

Atmis, E., Günşen, H. B., Lise, B. B., \& Lise, W. (2009). Factors affecting forest cooperative's participation in forestry in Turkey. Forest Policy and Economics, 11(2), 102-108. Available at: https://doi.org/10.1016/j.forpol.2008.10.002.

Awotide, D. O. (2012). Assessment of women's participation in cooperative societies and its determinants in Yewa North local government area of Ogun state, Nigeria. Asian Journal of Agriculture and Rural Development, 2(393-2016-23836), 344-350.

Ba, H. A., de Mey, Y., Thoron, S., \& Demont, M. (2019). Inclusiveness of contract farming along the vertical coordination continuum: Evidence from the Vietnamese rice sector. Land Use Policy, 87, 104050 . Available at https://doi.org/10.1016/j.landusepol.2019.104050.

Barrett, C. B., Bachke, M. E., Bellemare, M. F., Michelson, H. C., Narayanan, S., \& Walker, T. F. (2012). Smallholder participation in contract farming: Comparative evidence from five countries. World Development, 40(4), 715-730. Available at: https://doi.org/10.1016/j.worlddev.2011.09.006.

Bijman, J. (2008). Contract farming in developing countries: An overview. Working Paper, Wageningen University.

General Statistics Office. (2020). Statistical yearbook 2019. Hanoi: Statistical Publishing House.

Hussi, P., Murphy, J., Lindberg, O., \& Brenneman, L. (1993). The development of cooperatives and other rural organizations. Technical Paper No 199. Washington D.C: The World Bank.

Khong, T. D., Young, M. D., Loch, A., \& Thennakoon, J. (2018). Mekong River Delta farm-household willingness to pay for salinity intrusion risk reduction. Agricultural Water Management, 200(3), 80-89.

Khong, T. D., Loch, A., \& Young, M. D. (2019). Inferred valuation versus conventional contingent valuation: A salinity intrusion case study. Journal of Environmental Management, 243, 95-104. Available at: https://doi.org/10.1016/j.jenvman.2019.05.009.

Khong, T. D., Loch, A., \& Young, M. D. (2020). Perceptions and responses to rising salinity intrusion in the Mekong River Delta: What drives a long-term community-based strategy? Science of The Total Environment, 711, 134759. Available at: https://doi.org/10.1016/j.scitotenv.2019.134759.

Mesquita, L. F., \& Lazzarini, S. G. (2009). Horizontal and vertical relationships in developing economies: Implications for SMEs access to global markets. In New Frontiers in Entrepreneurship (pp. 31-66). New York: Springer.

Mighell, R. L., \& Jones, L. A. (1963). Vertical coordination in agriculture (No. 19). Farm Economics Division, Economic Research Service, US Department of Agriculture, Washington, DC, US

Min, Z. (2011). Vertical and horizontal linkages with small-scale farmers in developing countries: Evidence from China. The Ritsumeikan Economic Revierw, 60(3), 438-448.

Mitchell, J., Keane, J., \& Coles, C. (2009). Trading up: How a value chain approach can benefit the rural poor. London: COPLA Global: Overseas Development Institute.

Nguyen, N. C. (2009). Analysis of rice value chain in Can Tho city. Master Thesis. Can Tho University.

Nguyen, V. S. (2015). Agricultural restructuring in the context of narrowing Mekong Delta and solutions. Can Tho University Journal, 15(b), 246-263.

Ochieng, D. O., Veettil, P. C., \& Qaim, M. (2017). Farmers' preferences for supermarket contracts in Kenya. Food Policy, 68, 100111. Available at: https://doi.org/10.1016/j.foodpol.2017.01.008. 
People's Daily. (2015). Mekong Delta farmers contest advanced rice farming techniques. Retrieved from: https://nhandan.com.vn/tinhte/chuyen-lam-an/item/27904502-nong-dan-dbscl-thi.

Springer-Heinze, A. (2018). Valuelinks 2.0. Manual on sustainable value chain development, GIZ Eschborn. Deutsche Gesellschaft für Internationale Zusammenarbeit (GIZ) GmbH Division 4D, Climate Change, Rural Development, Infrastructure, Germany.

Trienekens, J. H. (2011). Agricultural value chains in developing countries; A framework for analysis. International food and Agribusiness Management Review, 14(2), 51-83.

Vo-Thi, T. L., \& Nguyen, P. S. (2011). Rice value chain analysis in the Mekong Delta. Journal of Can Tho University, 19a, 96-108.

Vo-Thi, T. L., \& Nguyen, P. S. (2013). Textbook of product value chain analysis, application in the field of agriculture (pp. 164). Can Tho: Can Tho University Press.

Vo-Thi, T. L., \& Nguyen, P. S. (2016). Textbook of product value chain analysis, application in the field of agriculture. Can Tho: Can Tho University Press.

Vo-Thi, T. L., Nguyen, V. L. E., Truong, H. V. T. K., Huynh, H. T., Doan, M. V., \& Lam, H. N. T. K. T. (2016). Review, analyze, evaluate and develop a plan to develop the value chain of the rice industry in Tra Vinh province. Can Tho: Can Tho University Press.

Vroegindewey, R. (2015). A framework for analyzing coordination in agricultural value chains: Evidence from cereal markets in Mali. Doctoral Dissertation, Michigan State University.

World Bank. (2012). Vietnam rice, farmers, and rural development: From successful growth to sustainable prosperity. Hanoi, Vietnam: World Bank.

Xiang, L. Y., \& Sumelius, J. (2010). Analysis of the factors of farmers' participation in the management of cooperatives in Finland. Journal of Rural Cooperation, 38(886-2016-64639), 134-155.

Zheng, S., Wang, Z., \& Song, S. (2011). Farmers' behaviors and performance in cooperatives in Jilin Province of China: A case study. The Social Science Journal, 48(3), 449-457. Available at: https://doi.org/10.1016/j.soscij.2011.05.003.

Zheng, S., Wang, Z., \& Awokuse, T. O. (2012). Determinants of producers' participation in agricultural cooperatives: evidence from Northern China. Applied Economic Perspectives and Policy, 34(1), 167-186. 